Jpn. J. Pharm. Health Care Sci.

ノ - ト 29(3) 305-311 (2003)

\title{
後発医薬品の供給体制，医薬品情報，包装単位についての調査
}

\author{
坂田 洋 \\ 春日井市民病院薬剂部†
}

\section{A Survey on the Status of a Drug Supply System, Drug Information and the Availability of Unit Sizes for Generic Drugs}

\author{
Hiroshi Sakata \\ Department of Pharmacy, Kasugai Municipal Hospital†
}

$\left[\begin{array}{l}\text { Received September 4, } 2002 \\ \text { Accepted January 18, } 2003\end{array}\right]$

We surveyed some significant factors related to the use of generic drugs, such as the stability of supply, the timeliness of package insert revisions, the existence and/or contents of "Interview Forms" (IF), the unit sizes and the locations of marketing offices. The drugs on which information was collected for this survey were ; 1) those normal carried by our hospital and had generic equivalents, and 2 ) those among the top 5 products both in terms of the frequency of prescriptions written and in terms of the total value of requested NHI reimbursements.

As a result we found the following information on the drugs studies : the products were sold through a direct sales route that did not involve a wholesaler, package inserts were less revised than the original drugs, IFs were not provided or, if they were, the contents were not sufficient (often not even easily obtainable data or references), the smallest unit provided were larger than the original drugs', and the manufacturers of generic equivalents did not have branch offices in the same prefecture as our hospital.

The product quality of the drugs remains a very important factor. However, in addition to the price, a stable source of supply for all drugs from which prompt delivery of the drug itself, as well as adequate product information are needed to ensure the safe and appropriate use of the products. As a result of the above investigations, the overall growth of the Generic Drug Market is expected to increase in the near future.

Keywords — generic drugs, stability of supply, package inserts, Interview Forms, drug information, unit sizes



平成14年度の診療報酬改訂では後発医薬品使用促進の ため，医科関連では後発医薬品を含んだ処方せん料と後 発医薬品を含まない処方せん料に差をつけるという改訂 が行われた。また，調剤報酬関連では医薬品品質情報提 供料および後発医薬品の調剂に係る加算が新設され，将 来の後発医薬品使用をより一層促進すると考えられる代
替調剤の可能性も示唆するような改訂が行われている. 一方，患者側から見た場合，薬剂費の一部負担金によ り投薬時の薬剤費が明示されることによるコスト意識の 高まりや，厚生労働省の HP に先発医薬品・後発医薬品 の対比が可能なリストが公表されたように，広く市民が 後発医薬品の情報を確認できるようになってきた.

このように後発医薬品をとりまく状況は, 使用を推進 する動きがより一層高まっている。

$\dagger$ 愛知県春日井市鷹来町 1-1-1；1-1-1, Takagi-cho, Kasugai-shi, Aichi, 486-8510 Japan 
後発医薬品としての品質については, 承認申請は先発 医薬品と異なり, 先発医薬品に比較して多くの試験が不 要とされているため, 後発医薬品と先発医薬品の同等性 を評価する目的で，1995年 4 月以降に発売された後発医 薬品については溶出試験が義務づけられたが, それ以前 は義務づけられていなかった，そのため1995年 4 月以前 に発売された後発医薬品については再評価を行い日本版 オレンジブックにより溶出試験の結果が公開されてい る. しかし溶出試験の結果からみた同等性に関する問題 点 ${ }^{1,2)}$ や，錠剤の硬度が単位時間あたりの溶出に及ぼす 影響了等が指摘されている. また後発医薬品と先発医薬 品における添付文書記載の違いによる問題点も指摘され ている゙).

一方，医薬品の使用に関しては製剤としての安全性・ 有効性, 医薬品の適正な使用に関する情報提供とともに 安定供給という点で支障があってはならない。

今回当院では, 後発医薬品について医薬品としての品 質以外に, 提供される添付文書の改訂状況や医薬品イン タビューフォームの内容㧍よび後発医薬品の供給体制等 について調查を行ったので報告する.

\section{方法}

\section{1. 当院の概要}

当院は愛知県名古屋市北部に隣接する春日井市立の公 立病院であり，概要はTable 1のとおりである.

\section{2. 調査対象とする薬牏}

平成14年度の診療報酬改定で後発医薬品を含む処方せ んと含まない処方せんで処方せん料に差をつけた改訂を ふまえ，外来で投薬に使用される薬郕とすることとし

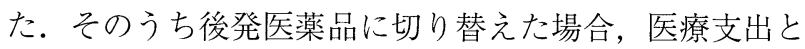
患者負担に大きな影響を与える薬剂と，多くの患者に使 用されるため後発医薬品に切り替えた場合に患者・診療 への影響が大きい薬剂を選択することとし，当院採用薬
剂のうち, 後発医薬品が薬価収載されている薬剤で医事 請求額の多い薬剤 5 品目および処方に記載される頻度が 多い薬剤 5 品目とした。

\section{3. 調査期間}

平成14年 6 月 17 日から平成14年 6 月 28 日の 12 日間

\section{4. 調查方法および調査内容}

対象となる後発医薬品発売メーカーに対して，当院と 取引のある医薬品卸の協力を得て資料の収集を行った。 協力を得た医薬品卸は 6 社で, その規模は 2001 年度売 上 $^{5)}$ 上位 10 社以内の卸が 4 社であり全国規模と地方規模 の卸それぞれ 2 社である。他の 2 社は中堅規模の数県を 地盤とする卸である。

調査する項目としては発売状況, 供給体制, 添付文書 · 医薬品インタビューフォーム (以下, インタビューフォー 厶と略す) - 医療用医薬品製品情報概要 (以下, 製品概要 と略す)の改訂状況および記載内容, 包装単位, 当院担 当支店・営業所の所在地である。

添付文書・インタビューフォームについては薬剤の使 用量, 医事請求額がともに上位に位置する薬剤, すなわ ちその薬効加みて多くの患者・医療従事者に医療情報 が必要とされる薬剤と考えられるロキソプロフェン錠に ついて詳細に調査を行った。

対応の迅速性を推測するためにも調査期間を区切り収 集することとした，添付文書等の依頼から収集期限(調 査終了日)までには 7 日間の間隔をあけることとした。

この調査期間内に収集できた添付文書，インタビュー フォーム, 製品概要等について, その改訂状況や記載項 目について調査した。

\section{結果}

調査対象となった薬剂は平成14年 5 月の 1 カ月に当院 で使用された内服薬のうち, 処方頻度順上位 5 品目と医

Table 1．春日井市民病院の概要

\begin{tabular}{|c|c|}
\hline 病床数 & 一般 550 床 感染症 6 床 計 556 床 \\
\hline 診療科 & $\begin{array}{l}\text { 内科、精神科、神経内科、呼吸器科、消化器科、循環器 } \\
\text { 科、小坚科、外科、整形外科、形成外科、脳神経外科、 } \\
\text { 呼吸器外科、心臟血管外科、皮膚科、泌尿器科、産婦人 } \\
\text { 科、眼科、耳鼻いんこう科、リハビリテーション科、放 } \\
\text { 射線科、麻酔科、歯科口腔外科 (計 } 22 \text { 科) }\end{array}$ \\
\hline 1日平均外来患者数 & 1800 人 \\
\hline 1日平均外来処方せん枚数 & 1086 枚 \\
\hline 院外処方せん発行率 & $71.1 \%$ \\
\hline 採用薬剂数 & 1347剂 \\
\hline 採用後発品数 & 57薬剤 \\
\hline
\end{tabular}

*数值はすべて平成 14 年 5 月のデータ 
事請求額順上位 5 品目であるが，処方頻度 1 位と医事請 求 2 位が同一薬剤であったため合計 9 品目である。9 品 目の医事請求額に占める割合は約 $7.5 \%$ あった。9 品 目の主な調査項目の結果は Table 2 のようであった。

\section{1. 発売および流通状況}

薬価収載されているがすでに発売が中止または流通し ていない薬剤がロキソプロフェン錠で 5 品目，エチゾラ ム錠 $0.5 \mathrm{mg}$ で 3 品目あった。

また，卸を経由して供給するメーカーは61(57.5\%)で あり，卸を通さずに直販制度等により販売していたり独 自の販売ルートなどにより製品を供給している医薬品 が，発売中止を除いた薬剤全体のうち半数近く $(42.5 \%)$ を占めた。

\section{2. 担当する支店の所在地}

当院と同一県内に当院を担当する支店のあるメーカー は販売中止をのぞいて $50 \%$ で，半数は担当支店または営 業所が同一県内になかった。

\section{3. 添付文書, インタビューフォーム, 製品概要}

添付文書については改訂状況を改訂年月および改定内 容について調査した. Table 3 は先発医薬品ロキソプロ フェン錠の添付文書改訂経過，Table 4 はその後発医薬 品の改訂状況である．改定点 $3,4,7$ は厚生労働省医薬 局安全対策課事務連絡による重大な副作用の改訂であ る。このうち 7 の改訂は今回の調査期間中に発生したの でこの改訂を除いた改定点 3 および 4 についてみると, 「後発医薬品さ錠」のように最大で10力月の差がある. 「後発医薬品さ錠」は改定点 6 を除く改定点 1 から改定
点 7 までの 1 年 2 カ月分の改訂を一度で改訂を行ってい る。

改定点 2 はメーカー自主改訂であるが「後発医薬品い 錠」のように2002年 1 月作成の添付文書でも改訂されて いないものがある。「後発医薬品な錠」では改定日を示 すアスタリスクが印字されていなかった。

インタビューフォームについては添付文書と同時に入 手できない医薬品がセンノシド錠 $12 \mathrm{mg}$ で 6 品目, 塩酸 チクロピジン錠で 5 品目, エチゾラム錠 $0.5 \mathrm{mg}$ で 3 品 目(販売中止を除く)等と少なからずみられた (Table 2$)$. インタビューフォームを作成していないという回答を得 たメーカーもあった。

インタビューフォームの記載内容については, 情報量 にそしく，一部ではほとんど添付文書と差がないものも あった。

有効成分の物理化学的性質, 臨床成績, 薬効を裏付け る試験, 非臨床試験についてはほとんどの薬剤に記載が なく，薬物動態や代謝に関しても乏しい記載内容となっ ている. Table 5 はロキソプロフェン錠のインタビュー フォームでヒトにおける体内動態・代謝・排泄について の有無を調査したものである。グラフとは別に数值が記 載されているものは $\mathrm{C}_{\max }, \mathrm{T}_{\max }$ では $90 \%$ 前後に記載が あるが $\mathrm{T}_{1 / 2}$ では数值は75\%であった. AUC, graphを含 めたこれらの項目以外はいずれも記載率は低率であっ た.これらの項目についてインタビューフォームの作成 された年月日を比較した場合，より新しく作成されたも のであっても情報の記載がないものがあった。

製品概要については，保存時の安定性が比較的不安定 な薬剤については，その点を記載したものが作成されて いたが，先発品との溶出性試験の同等性や体内動態を表

Table 2. 調查結果

\begin{tabular}{|c|c|c|c|c|c|c|c|}
\hline 先発医薬品 & 後発品数 & 販売中止等 & 卸経由供給 & IF（注1） & \begin{tabular}{|l} 
PTP包装単位 \\
(注2)
\end{tabular} & $\begin{array}{l}\text { ばら包装単位 } \\
\text { (注2) }\end{array}$ & $\begin{array}{l}\text { 担当所在地 } \\
\text { (注3) }\end{array}$ \\
\hline ブロチゾラム錠 & 14 & 0 & 7 & 11 & 13 & 11 & 8 \\
\hline センノシド錠 $12 \mathrm{mg}$ & 14 & 0 & 7 & 8 & 8 & 12 & 9 \\
\hline カルボシステイン細粒 & 2 & 0 & 0 & 1 & 1 & 1 & 2 \\
\hline ロキソプロフェン錠 & 27 & 5 & 16 & 20 & 20 & 17 & 11 \\
\hline エチゾラム錠 $0.5 \mathrm{mg}$ & 17 & 3 & 6 & 11 & 13 & 7 & 8 \\
\hline リマプロストアルファデクス錠 & 1 & 0 & 1 & 1 & 0 & -(注4) & 0 \\
\hline 塩酸チクロピジン錠 & 18 & 0 & 9 & 13 & 16 & 13 & 7 \\
\hline マレイン酸エナラプリル錠 $5 \mathrm{mg}$ & 20 & 0 & 14 & 18 & 19 & 9 & 7 \\
\hline ニコランジル錠 $5 \mathrm{mg}$ & 1 & 0 & 1 & 2 & 0 & 0 & 1 \\
\hline 合計 $(\%)$ & 114 & $8(7.0)$ & $61(57.5 *)$ & $85(80.2 *)$ & $90(84.9 *)$ & $70(66.0 *)$ & $53(50.0 *)$ \\
\hline
\end{tabular}

* : \%は発売中止を除いて集計

注1:期間内に収集できたインタビューフォーム数

注2：最小包装単位が先発と同じかそれ以下の製品があるメーカー数

注 3 : 当院と同一の県内に担当する支店・営業所があるメーカー数

注 $4:$ 先発品未発売 
Table 3.ロキソプロフェン錠の添付文書改訂状況

\begin{tabular}{|c|c|c|c|}
\hline 改訂点 & 改定日 & 改訂内容 & 改訂理由 \\
\hline 1 & 2001年 4 月 & $\begin{array}{l}\text { [使用上の注意 }] \\
\text { 9. その他の注意 } \\
\text { 非ステロイド性消炎鎮痛剤を長期間投与されている女性 } \\
\text { において、一時的な不妊が認められたとの報告がある。 }\end{array}$ & 自主改訂 \\
\hline 2 & 2001年8月 & $\begin{array}{l}\text { [使用上の注意 }] \\
\text { 1. 慎重投与 } \\
\text { 腎障害又はその既往のある患者 [浮腫、蛋白尿、血清クレ } \\
\text { アチニン上昇、高カリウム血症等の副作用がおこることが } \\
\text { ある。 }\end{array}$ & 自主改訂 \\
\hline 3 & 2001年8月 & $\begin{array}{l}\text { [使用上の注意 }] \\
4 \text {. 副作用 } \\
\text { (1) 重大な副作用 } \\
\text { 溶血性貧血（頻度不明）、白血球減少（頻度不明）、血小 } \\
\text { 板減少（頻度不明）：溶血性貧血、白血球減少、血小板減 } \\
\text { 少があらわれることがあるので、血液検査を行うなど観察 } \\
\text { を十分に行い、異常が認められた場合には值ちに投与を中 } \\
\text { 止し、適切な処置を行うこと。 }\end{array}$ & $\begin{array}{l}\text { 厚労省医薬局安全対 } \\
\text { 策課事務連絡 }\end{array}$ \\
\hline 4 & 2001年8月 & $\begin{array}{l}\text { [使用上の注意 }] \\
4 \text {. 副作用 } \\
\text { (1) 重大な副作用 } \\
\text { 急性腎不全（頻度不明）、ネフローゼ症候群（頻度不 } \\
\text { 明）、間質性肺炎（頻度不明）：急性腎不全、ネフローゼ } \\
\text { 症候群、間質性肺炎があらわれることがあるので、観察を } \\
\text { 十分に行い、異常が認められた場合には淔ちに投与を中止 } \\
\text { し、適切な処置を行うこと。また、急性腎不全に伴い高力 } \\
\text { リウム血症があらわれることがあるので、特に注意するこ } \\
\text { と。 }\end{array}$ & $\begin{array}{l}\text { 厚労省医薬局安全対 } \\
\text { 策課事務連絡 }\end{array}$ \\
\hline 5 & 2001年8月 & $\begin{array}{l}\text { [使用上の注意 }] \\
(3) \text { その他の副作用 発熱 }\end{array}$ & 自主改訂 \\
\hline 6 & 2002年6月 & 相互作用 メトトレキサート追記 & 自主改訂 \\
\hline 7 & 2002年 6 月 & $\begin{array}{l}\text { [使用上の注意 }] \\
4 \text {. 副作用 } \\
\text { (3) 重大な副作用 } \\
\text { 皮膚粘膜眼症候群（頻度不明）、中毒性表皮壊死症候群 } \\
\text { (頻度不明) : 皮膚粘膜眼症候群(Stevens-Johnson症候 } \\
\text { 群)、中毒性表皮壊死症候群（Lye11症候群）があらわれる } \\
\text { ことがあるので、観察を十分に行い、異常が認められた場 } \\
\text { 合には直ちに投与を中止し、適切な処置を行うこと。 }\end{array}$ & $\begin{array}{l}\text { 厚労省医薬局安全対 } \\
\text { 策課事務連絡 }\end{array}$ \\
\hline
\end{tabular}

下線部改訂部分

注：2002 年 4 月の組成、添加物および有効成分の改訂は略。

記するなどの後発品を使用する際に重要となる情報を記 載したものは少数であった。

\section{4. 包装単位}

今回調査した先発医薬品と後発医薬品の最小包装規格

を Table 6 に示した，薬価の比較的高い薬剤はPTP 製 剤についてはほとんどのメーカーが先発医薬品と同様の 包装単位を製造しているが，バラ包装ではややその率は 低下する．反対に薬価の低い薬剤についてはPTP 製剂 の包装単位も大型化する傾向がみられた。

その一方で先発医薬品より小さな包装単位を製造して
いるメーカーも存在した。



\section{1. 発売および流通状況について}

今回の調査では使用量・薬価請求額が多い薬剤である にもかかわらず，すでに発売が中止になっている薬剤が 8 品目あった。薬剤が発売中止になった場合, 院外処方 では保険薬局の薬品在庫が確認できないため処方への記 載が可能かどうかわからないといった問題や，患者側で は他の薬剤に切り替わった場合に外観が異なったり負担 金が異なる等の混乱が発生する可能性がある。 
Table 4. 後発医薬品の添付文書改訂状況

\begin{tabular}{|c|c|c|c|c|c|c|c|c|}
\hline 先発品の改定点 & 1 & 2 & 3 & 4 & 5 & 6 & 7 & 改訂年月日 \\
\hline 先発品改定日 & 2001 年4月 & $\begin{array}{l}2001 \text { 年8月 } \\
\end{array}$ & 2001年8月 & 2001年8月 & 2001年8月 & 2002年6月 & 2002年6月 & \\
\hline 後発品あ錠 & 0 & 2002年6月 & 0 & 0 & 2002年6月 & 2002年6月 & 2002年6月 & 2002年6月 \\
\hline 後発品い錠 & 0 & - & 2001年8月 & 2001年8月 & - & - & $\overline{-}$ & 2002 年1月 \\
\hline 後発品う錠 & 2001年5月 & - & 2001年8月 & 2001年8月 & - & - & - & 2001年5月 \\
\hline 後発品え錠 & 2001年4月 & - & 2001年8月 & 2001年8月 & - & - & - & 2001年8月 \\
\hline 後発品お錠 & 2001年8月 & - & 2001年8月 & 2001年8月 & $=$ & - & - & 2001年8月 \\
\hline 後発品か錠 & 2001年6月 &  & 2001年8月 & 2001年8月 & - & $\overline{-}$ & $\overline{-}$ & 2001 年8月 \\
\hline 後発品き錠 & 2001年11月 & 2001年11月 & 2001年11月 & 2001年11月 & 2001年11月 & $=$ & $\overline{-}$ & 2001年11月 \\
\hline 後発品<錠 & 2001年5月 & - & 2001年9月 & 2001年9月 & - & - & $\overline{-}$ & 2001年9月 \\
\hline 後発品け錠 & 0 & 2002年4月 & 2001年8月 & 2001年8月 & 2002 年 4 月 & $=$ & $\overline{-}$ & 2002年4月 \\
\hline 後発品こ錠 & - & - & - & - & - & - & - & 2001年3月 \\
\hline 後発品さ錠 & 2002年6月 & 2002年6月 & 2002年6月 & 2002年6月 & 2002年6月 & - & 2002年6月 & 2002年6月 \\
\hline 後発品し錠 & 2001年5月 & - & 2001年9月 & 2001年9月 & - & - & - & 2001年9月 \\
\hline 後発品す錠 & 2001年5月 & 2001年9月 & 2001年9月 & 2001年9月 & 2001年9月 & - & - & 2001年9月 \\
\hline 後発品せ錠 & 2001年8月 & 2001年10月 & 2001年10月 & 2001年10月 & 2001年10月 & - & - & 2001年10月 \\
\hline 後発品之錠 & 0 & - & 2001年8月 & 2001年8月 & - & - & - & 2001年8月 \\
\hline 後発品た錠 & 2001年5月 & - & - & - & - & - & - & 2001年5月 \\
\hline 後発品ち錠 & 2001年5月 & - & - & - & - & - & - & 2001年5月 \\
\hline 後発品つ錠 & 2001年7月 & 2002年4月 & 2002年4月 & 2002年4月 & 2002年4月 & - & 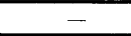 & 2002年4月 \\
\hline 後発品て錠 & 2001年5月 & - & 2001年9月 & 2001年9月 & - & - & - & 2001年9月 \\
\hline 後発品と錠 & 2001年5月 & - & 2001年8月 & 2001年8月 & - & - & - & 2001年8月 \\
\hline 後発品な錠 & 2001年4月 & 0 & 2001年8月 & 2001年8月 & 2001年8月 & $=$ & - & 2001年8月 \\
\hline 後発品に錠 & - & - & - & - & - & - & - & 2000年7月 \\
\hline
\end{tabular}

○：すでに改訂されており、改訂日が不明のもの

Table 5. 後発医薬品のヒトに扔ける薬物体内動態に関する記載

\begin{tabular}{|c|c|c|c|c|c|c|c|c|c|c|c|}
\hline 医薬品名 & 作成年月 日 & Cmax & Tmax & $\mathrm{T} 1 / 2$ & AUC & graph & $\begin{array}{c}\text { 吸収速度 } \\
\text { 定数 }\end{array}$ & $\begin{array}{c}\text { 消失速度 } \\
\text { 定数 }\end{array}$ & $\begin{array}{c}\text { 血漿蛋白 } \\
\text { 結合率 }\end{array}$ & 排泄部位 & 排泄率 \\
\hline 先発医薬品 & 2001年12月 & 0 & 0 & 0 & 0 & 0 & 0 & 0 & 0 & 0 & 0 \\
\hline 後発品あ錠 & 1999年2月 & 0 & 0 & 0 & 0 & 0 & & & & & \\
\hline 後発品い錠 & 2001年2月 & 0 & 0 & 0 & 0 & 0 & & 0 & 0 & 0 & 0 \\
\hline 後発品う錠 & 1999年1月 & 0 & 0 & 0 & 0 & 0 & & 0 & & & \\
\hline 後発品え錠 & 1998年7月 & & 0 & & 0 & 0 & & & & & \\
\hline 後発品お錠 & 2002年4月 & 0 & 0 & & $\mathrm{O}$ & & & & & & \\
\hline 後発品か錠 & 2000年7月 & 0 & 0 & 0 & 0 & 0 & 0 & 0 & & 0 & 0 \\
\hline 後発品き錠 & 1998年7月 & 0 & 0 & & 0 & 0 & & & & 0 & 0 \\
\hline 後発品け錠 & 2000年4月 & 0 & 0 & 0 & & & & & & & \\
\hline 後発品さ錠 & 1999年1月 & 0 & 0 & 0 & 0 & 0 & & & & & \\
\hline 後発品し錠 & 1998年7月 & 0 & 0 & & & & & & 0 & 0 & 0 \\
\hline 後発品す錠 & $\begin{array}{l}\text { 1998年7月 } \\
\end{array}$ & 0 & 0 & 0 & 0 & 0 & & & & & \\
\hline 後発品せ錠 & 2002年4月 & 0 & 0 & 0 & 0 & 0 & & & & & \\
\hline 後発品之錠 & 1998年7月 & 0 & 0 & 0 & 0 & 0 & & & & & \\
\hline 後発品た錠 & 1998年7月 & 0 & 0 & 0 & 0 & 0 & & & & & \\
\hline 後発品ち錠 & 2001年9月 & & 0 & 0 & & & & & & & \\
\hline 後発品つ錠 & 1998年7月 & 0 & 0 & 0 & & & & & & 0 & 0 \\
\hline 後発品て錠 & 1999年9月 & 0 & & 0 & 0 & 0 & & 0 & & 0 & \\
\hline 後発品と錠 & 1998年7月 & 0 & 0 & 0 & 0 & 0 & 0 & 0 & 0 & 0 & 0 \\
\hline 後発品な錠 & 2000年7月 & & 0 & & & 0 & & & 0 & 0 & 0 \\
\hline 後発品に錠 & 2000年7月 & 0 & 0 & 0 & 0 & 0 & & & & & \\
\hline 記載率 (\%) & & 85 & 95 & 75 & $7 \overline{75}$ & 75 & 10 & 25 & 20 & 40 & 35 \\
\hline
\end{tabular}

一方, 医薬品の購入については, 後発医薬品メーカー は先発医薬品メーカーと異なり，直販や代理店制で医薬 品を供給しているメーカーが多く見られた。当院のよう に薬品在庫を 5 日分程度に設定して発注の翌日に納品す る場合は，直販制度での発注から納品までに要する時間 によっては，在庫設定を見直す必要が生じる可能性があ り，また発注方法についても一般的には各卸の運営して
いるVAN は現時点では直販メーカーでは対応できない ため, 薬品管理システムにおける手順の変更や新たな負 担が発生するなどが考えられる。

\section{2. 担当する支店の所在地}

担当する支店の所在地は情報提供・収集という点で影 響を与えることが予想される。 
医療薬学 Vol. 29,No. 3 (2003)

Table 6. 先発医薬品と後発医薬品の最小包装規格

\begin{tabular}{|c|c|c|c|c|c|c|c|c|}
\hline \multirow{2}{*}{ 先発医薬品 } & \multirow{2}{*}{ 先発医薬品薬価 } & \multicolumn{3}{|c|}{ ヒート } & \multicolumn{4}{|c|}{ ばら } \\
\hline & & $<$ 先発品 & $=$ 先発品 & 先発品 $<$ & $<$ 先発品 & $=$ 先発品 & 先発品 $<$ & なし \\
\hline ブロチゾラム錠 & 36.00 & 0 & 12 & 2 & 0 & 8 & 3 & 3 \\
\hline センノシド錠 $12 \mathrm{mg}$ & 6.10 & 0 & 8 & 6 & 0 & 11 & 2 & 1 \\
\hline カルボシステイン細粒 & 23.50 & 0 & 0 & 2 & 1 & 1 & 0 & 0 \\
\hline ロキソプロフェン錠 & 26.20 & 0 & 19 & 3 & 1 & 14 & 3 & 4 \\
\hline エチゾラム錠 $0.5 \mathrm{mg}$ & 9.80 & 0 & 12 & 2 & 0 & 7 & 1 & 5 \\
\hline リマプロストアルファデクス錠 & 98.70 & 0 & 1 & 0 & 0 & 0 & 0 & 0 \\
\hline 塩酸チクロピジン錠 & 79.00 & 0 & 12 & 2 & 1 & 8 & 2 & 3 \\
\hline マレイン酸エナラプリル錠5mg & 97.70 & 0 & 19 & 1 & 0 & 3 & 7 & 10 \\
\hline ニコランジル錠 & 33.10 & 0 & 1 & 0 & 0 & 1 & 0 & $\underline{0}$ \\
\hline
\end{tabular}

現在, 添付文書については医薬品情報提供システムの ホームページからダウンロードが可能な状況にあり，添 付文書の入手という点では担当支店の所在地は意味を持 たないとも考えられる。しかし医薬品情報の改訂内容は 効能・効果の追加や重篤な副作用の追加など多種にわた り，また緊急性・重要性の程度により，お知らせやダイ レクトメール, Drug Safety Update等の手段によって伝 達される，とくに緊急安全性情報については，医療情報 担当者が原則として直接，医療機関の医師，薬剤師等の 医療従事者に厚生労働省医薬局安全対策課指示書受理後 4 週間以内に配布することと規定されている。このよう な規定を順守するためには，担当支店が遠隔地である場 合，実際には相当な困難が予想され，その詳細な情報の 入手・伝達は容易ではないと考える.

\section{3. 添付文書・インタビューフォーム・製品概要}

緊急安全性情報以外のメーカー自主改訂や厚生労働省 医薬局安全対策課事務連絡による改訂等については, 「医療用医薬品添付文書使用上の注意等の改訂に伴う情 報対応について」(昭和62年 4 月28日薬安第86号)によ り，厚生労働省医薬局安全対策課事務連絡は医療機関に 可能なかぎり 1 力月以内に伝達することと規定されてお り，またメーカー自主改訂は「事務連絡による場合」に 順じ，医療機関への伝達は，企業が改訂した日から，可 能なかぎり 1 力月を目安に伝達するように努めるとされ ている。これらの伝達には必ずしも添付文書自体の改訂 ではなく，改訂の内容を記載したお知らせ文書を作成し て伝達することでもよいので，今回の調査だけでは改訂 情報の伝達に問題があるとはいえない。しかし医療機関 としてもっとも好ましいことは伝達文書と改訂された添 付文書ができるだけ時間差なく入手できることである. 日常業務で質問等に対して回答する場合，ともすると改 訂連絡まで確認せずに未改訂の添付文書で回答してしま うことも考えられる.このような点からも重大な副作用 の改訂における10力月の時間差は大きすぎると考える.
メーカー自主改訂では医薬安全局事務連絡と異なり, 情報伝達経路が先発メーカーからの情報しかないと思わ れる。結果として医薬安全局事務連絡の改訂以上に時間 差を生じる可能性があるため，メーカー自主改訂時の情 報伝達経路の確立が望まれる。

また，今回の調査では最新とは考えられない添付文書 が提供されたメーカーが数社みられた。このようなメー カーについては情報の管理という点で疑問がある.

インタビューフォームについては作成義務がないため か入手できないメーカーがごく少数存在した。またその 内容は臨床で汎用される薬物体内動態であっても基本的 な事項以外の記載率は低いこと, 後発医薬品の承認申請 時に添付を必要としない項目では記載率が低いこと，一 部で引用されている文献は広く知られている文献である が半数以上のインタビューフォームに引用されていない こと等がわかった。これは作成年月日がより新しいもの であっても記載されていないものがあるという事実から もわかるように，作成時の情報量の差ではなく，後発医 薬品メーカーの情報収集能力や姿勢の違いと考えること もできる，承認申請時に必要とされない急性毒性・亜急 性毒性などの毒性や吸収・分布・代謝・排泄に関する項 目は，臨床の現場で沉用される項目でもある。これらの 情報が必要となった場合は，その都度メーカーに確認す る必要が生じるため, 今後このような点が改善すること なく後発医薬品の使用をさらに拡大した場合には，治療 を行う医師のみならず，医薬品情報の提供を行う薬剂部 の業務が煩雑になりかねない.

インタビューフォームの機能は添付文書に記載されて いる情報を補完犺するものである。そのためには引用で きる文献があるならば引用し改訂を重ねるたびに項目を 充足させることによって，医薬品メーカーとしての情報 提供の義務を果たすべきと考える。また，これらのデー 夕が先発医薬品メーカー以外から入手できないのであれ ば，デー夕を必要とする時には後発医薬品を使用しなが ら先発医薬品メーカーに頼らざるを得ないという矛盾に 
陥ることになる。したがって後発医薬品の使用を推進す るためには後発医薬品の情報を提供するシステム五が必 要ではないだろうか.

製品概要については，後発医薬品の性格上薬効や薬理 等についてはすでに広く知られているため，それらにつ いて記載することはあまり重要ではないと考える．後発 医薬品への切り替えについては事故防止の目的で，名称 や外観が類似した薬剤の一方を後発医薬品に切り替える ということも考えられる. その点からも後発医薬品にお ける製品概要については，製剤の写真などを記載して， すでに採用している薬剤と類似していないかどうかと いったことや，後発医薬品に要求される同等性等の情報 の記載が望まれる。

\section{4. 包装単位について}

医薬分業が進展し分業率が高まった今日，病院におい ても保険薬局においても，包装単位を使用量に見合った もので購入し，不良在庫を削減しなければならない。今 回の調査で後発医薬品であっても先発医薬品より少量の 包装があったことは好ましいが，反対に少量包装が用意 されていない薬剤も多く見られた.

特に薬価の低い薬剤では先発薬剤と同じ少量包装を用 意していない薬剤が多かった。

以上, 今回の調査から安定供給, 添付文書の更新時期, 添付文書やインタビューフォームに対するメーカーの取 り組み, 担当支店所在地の妥当性からみた情報提供の問 題点が明らかになったと考える。

これらはすべての後発医薬品にあてはまるわけではな く, 後発医薬品であってもその安定供給の点では先発医 薬品と同等であるものや, 情報量の点ではある程度の情 報量を提供している後発医薬品も存在する.

厚生労働省は今後, 今回の調査と同様な調査を行いそ の結果を公表していくとしている.

今回調査した薬剤はいずれも使用頻度の高い薬剤であ るため市場規模も大きいと考えられるが，それであって
も販売が中止されている薬剤があることからもわかると おり，後発品市場の経済環境も厳しいことがうかがえ る。しかしながら医薬品は生命に直接影響を与えるもの である，安価で質の高い医療を提供するために，後発医 薬品を使用することは有効な手段の一つと考えらえる が，医薬品である以上その品質は当然であるが，決して 薬価だけにこだわらず，薬剤に必須となる医薬品情報や 安定供給等といったことも基準に入れて取捨選択するこ とが，よりよい後発医薬品市場の育成につながると考え る.

\section{引用文献}

1）金本賢枝, 小西廣己, 㝨内徳蔵, 山路昭, 溶出試 験による後発医薬品の品質評価一塩酸チクロピジ ン製剤およびシメチジン製剤を対象としてー，日 病薬誌, 37, 1333-1335(2001).

2) 小川多津子, 大澤直, 内田享弘, 松山賢治, 後発 医薬品評価における病院薬剂師と薬科大学との連 携一ロキソプロフェンナトリウム錠の溶出試験を 例にしてー, 病院薬学, 26, 427-431(2000).

3）桝㴊泰宏, 堀江利治, ニコランジル製剤の製剂学 的検討, 医学と薬学, 37, 595-598(1997).

4）徳島裕子, 河野えみ子, 豊田佳代子, 曽川三千代, 高杉益充, 楽真澄, 先発医薬品と後発医薬品にお ける添付文書の比較ーアラセプリルとベザフィブ ラートの場合一，薬事新報，2131，1119-1123 (2000).

5）医療データランキング, CLINIC magazine 別冊, 381, 75(2002).

6) 三輪亮寿，伊賀立二，阿部正和，中村建，利部脩 二, 手島邦和, 日本製薬工業協会医薬品評価委員 会 PMS 部会, “医薬品担当者 MR 研修テキスト III”, 初版, 三輪亮寿, 中村建編, じほう, 東京, 2001, pp. 232.

7）大久保正，わが国における後発医薬品の現状と問 題点一後発医薬品の処方を阻害する要因とは一, 薬局，53，1745-1754(2002). 